\title{
THE ROLE OF PARENTS IN CHILDREN MEMORIZING THE QUR'AN IN MIDDLE SCHOOL BASED ON THE AMANATUL UMMAH ISLAMIC BOARDING SCHOOL
}

\author{
Mizanul Hasanah \\ Madrasah Tsanawiyah Unggulan Amanatul Ummah Mojokerto, Indonesia \\ Email:mizanulhazanah@gmail.com
}

\begin{tabular}{l} 
Keywords: \\
Islamic religious \\
education, the role \\
of parents, \\
memorizing the \\
Qur'an \\
\hline
\end{tabular}

Kata kunci: pendidikan agama islam, peran orang tua, penghafal al qur'an

\begin{abstract}
This article originated from the author's curiosity about the close inner relationship between parents and children who memorize the Qur'an. For the author of the Qur'an, it is Allah's revelation that was sent down directly to Rasulullah Muhammad SAW through the angel Gabriel. For this reason, the holy book of the Qur'an, which is very sacred and is the word of Allah, cannot be memorized if the individual does not appreciate, understand the signs, and glorify Allah before reading and memorizing it. One of them is filial piety to parents and do good to them. The author conducted direct research on the right target, namely the children who memorized the alquran in SMP-based Pesantren Amanatul Ummah Pacet. The aim of the author to conduct research at this location is that the children in the institution focus on producing Al-Quran memorizers. The method used in this research is descriptive qualitative research. Sources of data used are primary and secondary data sources and use data collection techniques in the form of interviews, observation and documentation.

\begin{tabular}{l} 
Abstrak \\
\hline Tulisan ini berawal dari rasa ingin tahu penulis tentang rekatnya \\
hubungan batin antara orang tua dan anak penghafal Al Qur'an. \\
Bagi penulis Al Qur'an merupakan wahyu Allah yang langsung di \\
turunkan pada rasullullah Muhammad SAW melalui perantaraan \\
malaikat Jibril. Karena itulah kitab suci Al Qur'an yang sangat sakral \\
\hline
\end{tabular}
\end{abstract}

http://pasca.jurnalikhac.ac.id/index.php/tijie/index 
dan merupakan kalam Allah tidak mungkin dihafal jika individu tersebut tidak menghayati, memahami rambu-rambu, serta mengagungkan Allah sebelum membaca serta menghafalkannya. Salah satunya yakni berbakti pada orang tua serta berbuat baik pada mereka. Penulis melakukan penelitian langsung pada sasaran yang tepat yakni anak anak penghafal alqur'an di SMP Berbasis Pesantren Amanatul Ummah Pacet. Tujuan penulis melakukan penelitian pada lokasi tersebut yakni anak anak yang ada dalam lembaga tersebut berfokus mencetak para pengahafal Al Qur'an. Metode yang digunakan dalam penelitian ini adalah penelitian kualitatif deskriftif. Sumber data yang digunakan adalah sumber data primer dan sekunder dan menggunakan teknik pengumpulan data berupa wawancara, observasi dan dokumentasi.

\section{INTRODUCTION}

The greatest miracle that was revealed to the Prophet Muhammad SAW was the Quran. It was revealed through the intercession of the angel Gabriel to the prophet Muhammad SAW which is written in the Mushaf. The main purpose of the Qur'an is to be a guide for all Muslims in the world and is a legacy of the Prophet, namely the Qur'an and Hadith. Another goal is to be read and listened to and listened to and contemplated so that it can be actualized in an applicative manner. The Qur'an is used as the first focus to deal with all problems related to the Islamic way of life, ways of thinking, and the consolidation of Islamic values ${ }^{1}$.

Learning the Qur'an is an obligation for Muslims. It is not only important for the needs of Islamic education but for the spiritual needs of humans in this life. Learning the Qur'an is a very noble activity, because in essence it indirectly becomes a servant's interaction with God Almighty. As the verse in the Qur'an Surah An Nisa 'verse 82.

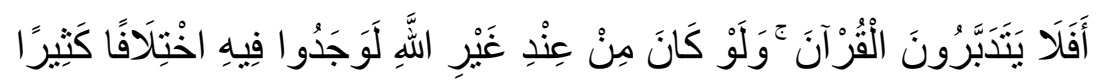

Meaning: Then do they not pay attention to the Qur'an? If the Qur'an were not from Allah's side, they would have had a lot of contradictions in it.

So, it has become an obligation for all Muslims in the world to study and understand the verses of the Qur'an, namely the holy book that is believed to be true. The way of life, events in this world, and life after death are all in the Qur'an

1 Nurasiah et al, "PENGARUH PENDEKATAN PEMBELAJARAN INDIVIDUAL TERHADAP CAPAIAN TARGET HAFALAN ALQURAN (Studi Kasus Di Kelas VIII A SMP Tahfidz Ar-Rasyid Kecamatan Cibinong Kabupaten Bogor)," Prosa PAI: Prosiding Al Hidayah Pendidikan Agama Islam 1, no. 1B (2018): 121-130. 
and we must believe in it. To maintain the authenticity of the Qur'an, namely by memorizing and practicing the contents of the Qur'an. In Islam, the Qur'an has a very high position, because the Qur'an is not only a holy book for Muslims but also as the first source of law and as a reference for resolving disputes.

Regardless of what education will be given to children from an early age, namely Islamic religious education where the first baton in educating children is through parents and family members. Islamic religious education is essentially not only needed in learning at school but also at home. Islamic religious education is education based on the teachings of Islam or Islamic religious guidance in an effort to foster and form a Muslim person who fears Allah SWT ${ }^{2}$.

Every love that is given by parents, to fellow creatures and the land, water, to the teacher is a gift from Allah SWT. Based on this, the tasks and functions that need to be carried out by Islamic education are complete education that lasts a lifetime. Apart from the above facts, very great attention has been paid to Islamic religious education by Islamic boarding schools as intensive educational institutions. Especially Islamic religious education in Islamic boarding schools. Moreover, currently there are many Islamic boarding schools with different backgrounds but one goal is to project pesantren as role models to foster character, character, social attitudes, and noble character so as to produce graduates who are competitive and have good character. So, Islamic religious education in Islamic boarding schools is not only material in class but is already at the stage of fostering and guiding children by example exemplified by asatidz (teachers) and kiai ${ }^{3}$.

In addition, the role of the family in Islamic religious education is the most important part because the first place for children to be raised is with their families. The family is a small part of the formation of character and the process of growth and development of children, both morally, personally, and spiritually, which is expected to be able to prepare the child's personality which is believed to shape his character Children who will grow up to become human beings who are beneficial to

2 Mizanul Hasanah, "ANALISIS MODEL REKRUTMEN DAN SELEKSI PENDIDIK DALAM KITAB TA'ALIMUL MUTA'ALLIM SYAIKH AZ-ZARNUJI," MANAGERE: Indonesian Journal of Educational Management 2, no. 1 (2020): 20-32.

3 Rofie, "Manajemen Kurikulum Pendidikan Agama Islam Berbasis Pesantren," Jurnal Reflektika 12, no. 2 (2018): 149-69. 
themselves and the people around them, especially for religion, nation and country. Indeed, in this case, an ideal family is needed in it. A family that has positive energy and synergizes with each family member ${ }^{4}$.

Especially parents as educators in the family environment must have knowledge of moral/moral education and must also know the obligations in educating children. Families that are able to prepare a generation of moral or noble character are families that are able to provide attitude or character education so that their personality is directed and professional. If their education is neglected and their personal formation is carried out unprofessionally, then they will be a disaster for parents, and a nuisance to society and mankind as a whole. Education in the family is very decisive in shaping children's morals. The moral strength of children's morals will be a filter in dealing with various life problems in the future ${ }^{5}$.

In addition, social support is an influence that includes the availability of resources that provide physical and psychological comfort obtained through the knowledge that the individual is loved, cared for, valued by others and he is also a member of a group based on common interests. There are also external factors such as public acceptance and appreciation of the memorizers. Thus, external factors such as the environment can be an important factor in growing motivation to memorize. Great public acceptance of memorizing the Qur'an will increase the spirit of memorizing the Qur'an. With good social acceptance and support from family or friends, physical and psychological comfort is obtained, so that a person is more enthusiastic in memorizing the Qur'an, because his family and friends have loved, paid attention, and appreciated all his activities. Some educational institutions even require, to be able to enter the institution must memorize several juz of the Koran. And the birth of the motivation to memorize is the greatest desire in an individual, as in the hadith narrates that someone who memorizes the Qur'an and always keeps

${ }^{4}$ Zaenal Abidin, Niken Fatimah Nurhayati, and Dwi Anggun Lestari, "Akhlak Mulia Ditinjau Dari Pendidikan Agama Islam Dalam Keluarga," Akhlak Mulia Ditinjau Dari Pendidikan Agama Islam Dalam Keluarga, 2018, 85-92.

5 Basidin Mizal, "PENDIDIKAN DALAM KELUARGA," Peuradeun, Jurnal Ilmiah Journal, International Multidisciplinary vol.2, No. (2014): 155-78. 
The Role of Parents in Children Memorizing The Qur'an In Middle School,...

his memorization will get the glory in the form of giving intercession (help) to ten members of his family on the Day of Resurrection ${ }^{6}$.

However, everyone's abilities are different. Children's intelligence is also different. The ability to memorize every human being is not the same, not everyone has a strong memory and not everyone has a strong intention and determination to memorize the Qur'an. Ambition, is a motive from within, as well as external influences that have a very large role in memorizing motivation. The teacher's role is very important to be able to increase motivation to memorize the Qur'an.

\section{RESEARCH METHODS}

The purpose of this research is to describe, explain, analyze and design. Starting from describing how the condition of the students' activities while at the cottage, the method of memorizing, the teacher as well as the desires and hopes that they aspired to, which so far are not widely known. Both in the form of motivation and expressions of their feelings who always interact with the Qur'an every day. So this research is a type of qualitative research with a descriptive approach. Qualitative descriptive analysis method is to analyze, describe, and summarize various conditions, situations from various data collected in the form of interviews or observations about the problems studied that occur in the field ${ }^{7}$.

In this case, the resource persons are students at SMP BP Amanatul Ummah Pacet who have completed 30 chapters. Researchers focus more on the perspective of children towards their parents. In addition, the instrument used was the researcher himself by conducting direct interviews with children who memorized the Qur'an at BP SMP based on the Amanatul Ummah Pacet Islamic Boarding School.

Meanwhile, according to Sugiyono, it is an analytical method based on the philosophy of postpositivism, used to examine the condition of natural objects, where the researcher is the key instrument. The results of qualitative research emphasize meaning rather than generalization. This research method is often used to examine the condition of natural objects, namely objects that develop as they are,

\footnotetext{
${ }^{6}$ M. Nurul Huda, “Budaya Menghafal Al-Quran: Motivasi Dan Pengaruhnya Terhadap Religiusitas," Sukma: Jurnal Pendidikan 2, no. 2 (2018): 247-60, https://doi.org/10.32533/02205.2018.

7 Sugiono, Memahami Penelitian Kualitatif (Bandung: Alfabeta, 2015).
} 
not manipulated by researchers, and the presence of researchers does not affect the dynamics of the object where the researcher is the key instrument. In qualitative research, the problem formulation is the focus of research which is still temporary and will develop after the researcher enters a particular field or social situation with a view to understanding complex social phenomena.

\section{RESULTS AND DISCUSSIONS}

\section{Discussions}

\section{Islamic Religious Education in Children}

The main goal in Islamic religious education is that humans are given a clear, complete and comprehensive picture. Especially the morals that need to be trained through activities of reading the Qur'an, evening prayers, fasting, sunnah, always staying in touch with family and society. Through this activity, the child will be self-directed towards the values of goodness and make these activities a daily necessity in living life. There are three important things that must be consistently taught to students, namely (1) kidah/faith education, to produce future young people who are strong in imtaq (faith and piety) and avoid misleading streams such as juvenile delinquency, drug abuse, promiscuity, which lately is very worrying. (2) worship education, taught to children from now on so that children have commitments such as habituation to obligatory and sunnah worship. This is where the role of parents and teachers is needed in setting good examples and examples. (3) moral education, the most important education for children is to instill good values. Give birth to a rabbinic generation, or a generation that is pious, intelligent, and has noble character. Therefore, it is necessary for the role of parents and teachers both in the school environment and outside the school ${ }^{8}$

Such efforts are not easy to apply in everyday life. It takes cooperation and sincerity in educating children. Instilling Islamic education for children will not run optimally and consistently without serious involvement from all parties. Therefore,

8 Muchammad Ainul Yaqin, "PENDIDIKAN AGAMA ISLAM DAN PENANGGULANGAN KENAKALAN SISWA (Studi Kasus MTs Hasanah Surabaya)," Jurnal Pendidikan Agama Islam (Journal of Islamic Education Studies) 4, no. 2 (2016): 293, https://doi.org/10.15642/pai.2016.4.2.293-314. 
all elements and stakeholders are certainly given the opportunity to oversee better education ${ }^{9}$.

Motivation in learning, especially in memorizing is a supporting factor that can optimize children's intelligence and bring them to achieve achievements. Children with high learning motivation will generally have good learning achievements. Conversely, low motivation will make children's achievement decline. Because motivation is a change in energy within a person which is characterized by an affective impulse and reactions to achieve goals. Motivation will encourage children to try their best to achieve learning goals. He will also study earnestly without being forced.

A person's greatest motivation is from oneself, but external factors also have a major influence on children, especially the motivation of the child's parents. Parental attention is the key to a child's success, both at school and outside of school. Therefore, the role of parents is very important in the education and development of children. Parental attention is parental attention to all the needs of their children, both material and spiritual attention.

Attention is not only limited to material needs in meeting children's needs, both food, shelter, and clothing as well as other needs, but non-material needs such as support, encouragement, affection and attention to children's difficulties in the teaching and learning process at school ${ }^{10}$.

With the descriptions above, the researcher believes that good parental attention at home will foster good student motivation or motivation, especially in memorizing children's Al-Qur'an. The attention given by parents, such as attention to the need for memorizing the Qur'an of children at school, will foster good motivation for memorizing the Qur'an for children. The child will think that his parents work hard and pay attention to the need for education costs, so he must memorize the Qur'an well so as not to disappoint people, so he is diligent in

9 Muhammad Anas Ma'arif, "Analisis Konsep Kompetensi Kepribadian Guru PAI Menurut Az-Zarnuji," Istawa: Jurnal Pendidikan Islam, 2017, https://doi.org/10.24269/ijpi.v2i2.624.

10 Agus Mifta Surur, "Upaya Menanamkan Nilai Religius Siswa Di Man Kediri 1 Kota Kediri Dengan Ekstrakurikuler Keagaman Tahfidz Al-Qur'an," Jurnal Pendidikan Agama Islam 15, no. 1 (2018): 42-51, https:/ / doi.org/10.14421/jpai.2018.151-03. 
memorizing the Qur'an at school and at home. Children who do not get the attention of parents make children not care about memorizing the Qur'an, therefore parents must pay attention to children, such as attention to methods. recite the hijaiyah letters, the difficulties experienced by children in memorizing long verses, helping children memorize the Qur'an with methods that are easily accepted by children so that memorizing the Qur'an is not a burden for children.

\section{The role of parents in educating children to memorize the Qur'an}

It is no stranger to meet the word role in this life, one of which is the role of parents. Role is a dynamic aspect of a person's position (status). If a person has carried out his rights and obligations, he has actually carried out his function.

In essence, the role played by each person is different. A teacher is said to carry out his function when he succeeds in carrying out his function, namely educating and fostering his students well. Parents, too, are said to be good at carrying out their functions when they succeed in educating their children to be obedient and obedient to goodness. State officials also carry out their functions properly if the role they carry out can make the country fair, prosperous, prosperous. A person's personality also affects how that role can be carried out. In essence, the role can also be formulated as a series of certain behaviors caused by a certain position. A person's personality also affects how that role should be carried out $^{11}$.

The role is an action or behavior carried out by someone who occupies a position in social status, the terms of the role include 3 (three) things, namely: (1) The role includes the norms associated with a person's position or place in society. Role in this sense is a series of rules that guide a person in social life. (2) Role is a concept of what behavior can be carried out by individuals in society as an organization. Role can also be said as individual behavior, which is important for the social structure of society. (3) The role is an orderly series that is caused by a position. Humans as social beings have a tendency to live in groups. In group life, there will be interaction between members of one community with other

11 Hasyim Asy'ari, "PERAN ORANG TUA DALAM IMPLEMENTASI PROGRAM KEAGAMAAN ANAK USIA DINI PADA KB-TK AN-NISA KRIAN SIDOARJO," Martabat: Jurnal Perempuan Dan Anak 3, no. 1 (2019): 103-120. 
The Role of Parents in Children Memorizing The Qur'an In Middle School,...

community members. The growing interaction between them there is interdependence. In social life, what is called a role emerges. The role is a dynamic aspect of a person's position, if a person carries out his rights and obligations according to his position, the person concerned carries out a role ${ }^{12}$.

Parents are biological fathers and mothers or people who are considered wise, respected, admired, and elder. This shows that the meaning of parents is not limited to biological parents but rather an elder or respected figure. In general, the meaning of parents means people who play an important role in raising children from birth to adulthood. Some even start small from an early age to adulthood. Both biological and social relationships. There are many versions that can describe the meaning of parents. Parents are adults who bring children into adulthood, especially in the developmental period. The task of parents is to equip and prepare children for adulthood by providing guidance and direction that can help children in living life. In providing guidance and direction to children, it will be different for each parent because each family has certain conditions that differ in style and nature from one family to another ${ }^{13}$.

Parents act as the first and foremost educators in the family environment. Because parents have a very strong inner bond for children, so the role of parents is very decisive as motivation. The family is a child's first school as a supervisor for his growth and development. The role of the family for a child is the most important thing to believe in instilling attitudes and values in life and directing children to goodness. Kindness such as children's talents that begin to appear and must be developed, children's different interests that must be directly supervised by the family and develop their personality. Those who act as educators in religious education in the family are parents, namely father and mother and all those who are responsible for the development of the child such as grandfather, grandmother,

12 Hasan Baharun, "Pendidikan Anak Dalam Keluarga; Telaah Epistemologis," Jurnal Pedidikan 3, no. 2 (2016): 96-107.

13 Djaelani, "Peran Pendidikan Agama Islam Dalam Keluarga Dan Masyarakat," Jurnal Ilmiah WIDYA 1, no. 1 (2013). 
uncle, aunt and brother. However, overall these roles are better guided directly by fathers and mothers ${ }^{14}$.

Parents have an obligation to give attention and affection as well as physical and spiritual development of their children with the aim that children can develop optimally both emotionally, spiritually and intellectually. For this reason, parents as educators of children outside of school life must have basic knowledge for the growth and development of their children. One of them is to direct the interests and talents of the child. It is well realized that there is a need for a special method that is right for parents to direct the interests and talents of the child. Parents must be gentle with children but do not make them negligent in their duties as children, namely respecting their parents and not forcing their will on children. That's why special methods are needed to educate and nurture children. Specifically educating children to memorize the Qur'an.

Every child is an individual who cannot be compared to clay that can be "shaped" at will by parents. However, it must be adjusted to the development of the soul and potential of the child as a sign of parental love and moral responsibility which is consistently based on a trusted attitude and has a relationship pattern between awareness of obligations and obedience to parents for that awareness.

\section{RESULTS}

The research that the author conducted at the Amanatul Ummah Islamic Boarding School-Based Middle School educational institution which focused on students memorizing the Qur'an was broadly described through interviews, observations, and research results in the field. The research shows that

\section{Parents set an example and give orders}

Parents are role models for children in everyday life. Even though children are entrusted to trusted institutions such as pesantren and so on. The involvement of parents in educating children to memorize the Qur'an does not necessarily hand over all responsibilities to the teacher/ustadz/ustadzah.

14 Yudhi Fachrudin, "Pembinaan Tahfizh Al-Quran Di Pesantren Tahfizh Daarul Qur'an Tangerang," Kordinat: Jurnal Komunikasi Antar Perguruan Tinggi Agama Islam 16, no. 2 (2017): 325-48, https://doi.org/10.15408/kordinat.v16i2.6445. 
Based on the interviews that the researchers conducted with the students of SMP Amanatul Ummah, namely as described by Ananda ZA:

"Alhamdulillah, if you are at home, ustadzah.. Mama always reminds me after mahrib and dawn to repeat and add memorization. After every maghrib prayer read the Qur'an and memorize 2 verses and after dawn too, at least in a day memorize 2 verses. Already but not every day, sometimes. Sometimes my mother listens to my reading. Hehe.. like a cleric in the cottage. Indeed, I am not a memorizer, but I can read the Qur'an and the correct tajwid. If mom says always, please forgive me, I'm not as good as you, nduk. But I want you to run smoothly and become a memorizer of the Qur'an. Mama never forgets to give Ustadzah's spirit... every time she calls through the supervisor's cellphone."

Based on the interviews that the researchers conducted with the students of

SMP Amanatul Ummah, namely as described by Ananda HA:

Already but not every day, sometimes. Usually tiqror (repeat) memorization with ummi while listening to the child's memorization. Ummi is not a person who is too familiar with religion, especially in terms of memorizing the Qur'an, just being able to listen. Are there any skipped readings? Umi says always to me, I' $m$ sorry, Le ummi can only support your school activities. The important thing is that you are diligent. Umm is happy.

Based on interviews that the researchers conducted with the students of SMP

Amanatul Ummah, namely as described by Ananda AM:

Alhamdulillah, now it's 30 juz us.. mom and dad are very happy. Their desire is that after this I study abroad to become a hafidzoh and scientist. Since elementary school, my mother sent me to SDIT and there was an extra tahfidz tone. Mama also memorized the Qur'an but not all of it. My sister in high school also received the same treatment. But bro, it's not 30 juz yet, God willing, soon. I am always encouraged by my mother so that I can study abroad, especially papa... will continue to support me. Because that's what makes me excited to memorize. We miss home. But, you have to keep the spirit said papa. Let's be like a brother.

Based on the results of the interviews above, some parents have tried to provide examples or examples for children in memorizing the Qur'an and there are also parents who have not been able to provide examples or examples due to parents who do not have a lot of memorization.

\section{Parents give encouragement (motivator)}

Motivation is the initial baton for achieving goals. A child has the motivation to move and act with the encouragement of those around him, especially encouragement from parents. Motivation can be in the form of giving positive words such as enthusiasm, giving awards, hopes, gifts when a child succeeds in achieving something valuable in his life. 
Especially motivation and encouragement from parents are needed by children to memorize the Qur'an, because memorizing the Qur'an really requires strong will and discipline. Parents must be able to motivate children and foster the spirit of memorizing the Qur'an in children in memorizing the Qur'an so that children are always enthusiastic in memorizing the Qur'an. As explained by HA:

"Alhamdulillah, father and mother never forced their will on me to become a memorizer of the Qur'an. They are quite happy if I do an activity voluntarily. This is my motivation, I want to give the best for them. Give my recitation of the Qur'an in front of Allah later in the hereafter. My parents never give gifts to children, because of the mediocre economic conditions there are still many other things that are needed. I only buy what I need for school and I think that's enough. Later, if I give my child a gift, I am afraid that I will be spoiled and negligent and all must be obeyed. The gift doesn't have to be in the form of goods, usually if I can memorize it according to my target, I give double the pocket money, that's all I'm happy and even more enthusiastic about memorizing, but once at that time he could finish 1 juz I bought a bicycle. Usually the mother is told to repeat the memorization, if it is difficult to memorize with umi. Memorizing the Qur'an with Ummi was encouraging because Ummi was helped, dictated by Ummi word for word to make it easier. If you can memorize 2-5 verses that ummi asks for, usually you will be given additional pocket money for school".

Based on the interviews that the researchers conducted with the students of

SMP Amanatul Ummah, namely, as explained by ZA:

"Already in the form of encouraging and supporting facilities for their children, such as frequently tuning murattals to help children memorize or remember, there is time to check memorization during night study. If parents are busy I repeat the previous memorization before adding. Actually, parents don't want to burden their children with having to reach the memorization target, they tend not to burden their children with memorizing."

Based on interviews that researchers conducted with students of SMP BP

Amanatul Ummah, namely, as explained by AM:

"I personally tend to be competitive. So, if others have more achievements, I want to be like him. Want to compete in goodness if papa said. Stay focused on the goals and ideals, God willing, brothers and sisters to be successful people. That's what dad said. Papa, Mama are the best ustadzah"

Based on the results of the interview above, parents assume that the child's motivation is in the form of gifts, even though other actions such as giving praise and body movements such as stroking his head are already motivation for children. Giving praise, small gifts or punishments is a form of reward and sanctions for children so that they are more motivated in an activity, especially in memorizing the Qur'an. There are also examples of families in which they have positive energy. 
The Role of Parents in Children Memorizing The Qur'an In Middle School,...

Making their children successful through motivational words so that the child memorizes the Qur'an without coercion. Caring for and flattering one another.

\section{Parents give duties and responsibilities}

Duties are obligations that must be carried out by someone in their duties, and responsibility is a must to carry out all obligations or tasks assigned to him and responsibilities cannot be delegated to others. The task of a student is to study well, and do the schoolwork that has been given by the teachers at school.

When the child is at home, parents should give the task and responsibility to the child by ordering the child to learn, repeating the memorization of the Qur'an that has been memorized so as not to forget or add to its memorization, doing positive things, discipline and responsibility. to what is done.

Based on the interviews that the researchers conducted with the students of SMP Amanatul Ummah, namely, as explained by ZA:

"More to my father. My father always emphasized that 9th graders had to have a heart, right? Because I have memorized since SDIT. Currently my memorization is 25 juz. I am sitting in 8 th grade. Pray for a ustadzah"

Based on the interviews that the researchers conducted with the students of SMP Amanatul Ummah, namely, as explained by HA:

"memorize what you can, but don't forget to nderes"

Based on the interviews that the researchers conducted with the students of SMP Amanatul Ummah, namely, as explained by AM:

"Always called through the cleric's cellphone, for example. Hey, how many verses have you reached this week, what surah? Spirit, yes, you have to be enthusiastic about memorizing a lot, right?"

Based on the above, it shows that in the process of memorizing the Qur'an it is necessary to instill a great sense of responsibility so that children can carry out their duties well.

\section{Parents give a chance to try}

A child when forced to always memorize the Qur'an continuously will get bored. Parents should give children the opportunity to try by giving children the freedom to memorize and parents only monitor by accompanying, directing and correcting what the child has done. This is good for parents to do because children have the opportunity to try so that children have a lot of knowledge and of course must be under supervision and direction from parents. 
Based on the interviews that the researchers conducted with the students of SMP Amanatul Ummah, namely, as explained by ZA:

"Besides at school, which requires rote memorization, my parents always accompany me at home to memorize." If after doing misla activities, you finish playing games, and eat, and pray. Always called by mama to "let's go nderes son".

Based on the interviews that the researchers conducted with the students of

SMP Amanatul Ummah, namely, as explained by HA:

"If I memorized it at home, I did have an awareness of memorizing and nderes myself. Ummi does accompany but it's not always full 24 hours because she has to take care of the house and orders."

Based on the interviews that the researchers conducted with the students of SMP Amanatul Ummah, namely, as explained by AM:

"Mom and Papa always remember us at home. After the morning and evening prayers. Later, Mom will hold the Qur'an and I will memorize at least 3 juz."

So, in this case, parents also need to give children the opportunity to try to memorize the Qur'an in their own way so that parents know their child's abilities. However, in this case, parental supervision is needed so that children continue to memorize the Qur'an properly and correctly.

\section{Parents carry out supervision and checks}

Parents carry out supervision and checks properly and parents also try to understand children with assistance and guidance in memorizing will make children feel cared for so that children will be more enthusiastic about memorizing.

Based on the interviews that the researchers conducted with the students of SMP Amanatul Ummah, namely, as explained by ZA: "If you are at home, you will be supervised, but if you are at the cottage, you will only ask questions by telephone".

Based on the interviews that the researchers conducted with the students of SMP Amanatul Ummah, namely, as explained by HA:

"Sometimes you are asked to memorize, sometimes you don't, ma'am. Because I've been in the cottage for a long time. Mom always orders by phone, which is a blessing, mas. You memorize add Alhamdulillah. If not, then you have to keep going. Let's not get lost. That's Umi's message, if the visit, it's through.

Based on the interviews that the researchers conducted with the students of 
SMP Amanatul Ummah, namely, as explained by AM:

"Mama always monitors through the cellphone of Ustadzah Tahfidz, always asks for the progress of memorization. You know, Ustadzah always conveys it, don't remember Mama's message, it's easy and quick to hate. If you are lazy, you are always reminded to make a deposit. Mama is so caring"

Memorizing the Qur'an is one of the noble deeds that requires strong will and discipline. The involvement and role of parents towards children in memorizing the Qur'an is very necessary, because children spend a lot of time with their parents and without the involvement of parents it is a failure. Parents are the most responsible for their children, especially in terms of memorizing the Qur'an, it is the duty of parents to always bring their children closer to the Qur'an, and guide them to memorize the Qur'an. The involvement of parents with children in memorizing the Qur'an will have a positive impact on children so that children are more enthusiastic about memorizing the Qur'an and their child's memorization will also be better. Children whose academic ability is lacking, but if parents always motivate them, then the child can be on par with friends who have good academic abilities and children who have good academic abilities and are supported by motivation from their parents, the results of the child will be even better. .

Overall, related to the role of parents in motivating children to memorize the Qur'an at SMP BP Based on the Amanatul Ummah Islamic Boarding School, many parents have done well and children can meet the memorization targets that have been determined by the Tahfidz teacher. We can conclude this through interviews with their children. Although the more active role is the mother. Fathers should also play an active role in guiding children in memorizing the Qur'an, not only delegating the responsibility to the mother, because the task of guiding and assisting children to memorize the Qur'an is the duty of the father and mother.

\section{CONCLUSION}

School is a place of dedication for a teacher. Where it becomes a place to devote all thoughts and energy to direct children to goodness. In this case the teacher is meant not only as a profession but a calling for many people in this world. Parents are also teachers, namely teachers for their children. Even though their container is not at school. However, it has a wider area than the school. Usually in the family 
religious values are instilled to shape the behavior of children. Therefore, religious education in the family is needed to know the boundaries of good and bad in everyday life. Religious education is expected to encourage every human being to do something with his conscience. Given the importance of family education in building human resources (HR) with character and morality, it is necessary to understand the right education.

Based on the research that has been done by researchers, it shows that the role of parents in children memorizing the Qur'an is good. This is shown by how the sense of care and love that is poured out on the child through interviews is very clearly illustrated. Among other things the ideals of those who want to gift the crown of light to their parents. The enthusiasm that is always given when communicating via whatsApp telephone and the attention they give not only to children but to ustadz and clerics who guide them directly to memorize the Qur'an.

In addition, researchers found that there is a motivation for children in the social environment, namely pride among friends, relatives, family, and neighbors. So the author draws the conclusion that the motivation of children memorizing the Qur'an is not only the role of parents but also their social environment. In addition, what attracted the author's attention was that the average resource person who was a child who memorized the Qur'an at Amanatul Ummah Pacet Islamic Boarding School-Based Middle School said that when they were at home, for example, such as semester breaks, both parents had played their role well in guiding and directing their children in memorizing the Qur'an is like parents giving examples and giving orders to imitate, parents giving encouragement (motivators), parents giving tasks and responsibilities, parents giving opportunities to try, and parents conducting supervision and checking.

\section{REFERENCES}

Abidin, Zaenal, Niken Fatimah Nurhayati, and Dwi Anggun Lestari. "Akhlak Mulia Ditinjau Dari Pendidikan Agama Islam Dalam Keluarga." Akhlak Mulia Ditinjau Dari Pendidikan Agama Islam Dalam Keluarga, 2018, 85-92. 
The Role of Parents in Children Memorizing The Qur'an In Middle School,...

Asy'ari, Hasyim. "PERAN ORANG TUA DALAM IMPLEMENTASI PROGRAM KEAGAMAAN ANAK USIA DINI PADA KB-TK AN-NISA KRIAN SIDOARJO." Martabat: Jurnal Perempuan Dan Anak 3, no. 1 (2019): 103-120.

Baharun, Hasan. "Pendidikan Anak Dalam Keluarga; Telaah Epistemologis." Jurnal Pedidikan 3, no. 2 (2016): 96-107.

Djaelani. “Peran Pendidikan Agama Islam Dalam Keluarga Dan Masyarakat." Jurnal Ilmiah WIDYA 1, no. 1 (2013).

Fachrudin, Yudhi. “Pembinaan Tahfizh Al-Quran Di Pesantren Tahfizh Daarul Qur'an Tangerang." Kordinat: Jurnal Komunikasi Antar Perguruan Tinggi Agama Islam 16, no. 2 (2017): 325-48. https:/ / doi.org/10.15408/kordinat.v16i2.6445.

Hasanah, Mizanul. “ANALISIS MODEL REKRUTMEN DAN SELEKSI PENDIDIK DALAM KITAB TA'ALIMUL MUTA'ALLIM SYAIKH AZ-ZARNUJI." MANAGERE: Indonesian Journal of Educational Management 2, no. 1 (2020): 2032.

- - - . "Sistem Informasi Manajemen Pendidikan Keluarga Dalam Islam Berdasarkan Al-Qur'an Dan Al-Hadits." Islamuic Management: Jurnal Pendidikan Islam 53, no. 9 (2019): 1689-99. https:/ / doi.org/10.30868/im.v3i01.629.

Helpris, Estaswara. Stakeholder Relation. Jakarta: Universitas Pancasila, 2010.

Huda, M. Nurul. “Budaya Menghafal Al-Quran: Motivasi Dan Pengaruhnya Terhadap Religiusitas." Sukma: Jurnal Pendidikan 2, no. 2 (2018): 247-60. https://doi.org/10.32533/02205.2018.

Ma'arif, Muhammad Anas. “Analisis Konsep Kompetensi Kepribadian Guru PAI Menurut Az-Zarnuji." Istawa: Jurnal Pendidikan Islam, 2017. https://doi.org/10.24269/ijpi.v2i2.624.

Ma'arif, Muhammad Anas. "Hukuman (Punishment) Dalam Perspektif Pendidikan Di Pesantren." Ta'allum: Jurnal Pendidikan Islam 5, no. 1 (2017): 1-20. https://doi.org/10.21274/taalum.2017.5.1.1-20.

Mizal, Basidin. "PENDIDIKAN DALAM KELUARGA." Peuradeun, Jurnal Ilmiah Journal, International Multidisciplinary vol.2, No. (2014): 155-78.

Mulyadi, Mohammad. "Penelitian Kuantitatif Dan Kualitatif Serta Pemikiran Dasar Menggabungkannya." Jurnal Studi Komunikasi Dan Media 15, no. 1 (2013): 128. https://doi.org/10.31445/jskm.2011.150106. 
Mizanul Hasanah

Noer, Muhammad Ali, and Azin Sarumpaet. "Konsep Adab Peserta Didik Dalam Pembelajaran Menurut Az-Zarnuji Dan Implikasinya Terhadap Pendidikan Karakter Di Indonesia." Al-Hikmah: Jurnal Agama Dan Ilmu Pengetahuan 14, no. 2

181-208.

http://journal.uir.ac.id/index.php/alhikmah/article/view/1028.

Nurasiah et al. "PENGARUH PENDEKATAN PEMBELAJARAN INDIVIDUAL TERHADAP CAPAIAN TARGET HAFALAN ALQURAN (Studi Kasus Di Kelas VIII A SMP Tahfidz Ar-Rasyid Kecamatan Cibinong Kabupaten Bogor)." Prosa PAI: Prosiding Al Hidayah Pendidikan Agama Islam 1, no. 1B (2018): 121-130.

Rofie. “Manajemen Kurikulum Pendidikan Agama Islam Berbasis Pesantren.” Jurnal Reflektika 12, no. 2 (2018): 149-69.

Sugiono. Memahami Penelitian Kualitatif. Bandung: Alfabeta, 2015.

Surur, Agus Mifta. “Upaya Menanamkan Nilai Religius Siswa Di Man Kediri 1 Kota Kediri Dengan Ekstrakurikuler Keagaman Tahfidz Al-Qur'an." Jurnal Pendidikan Agama Islam 15, no. 1 (2018): 42-51. https://doi.org/10.14421/jpai.2018.151-03.

Wahyu Praban Danu. "IMPLEMENTASI KEBIJAKAN SEKOLAH BERBASIS PESANTREN DI IMPLEMENTATION OF SCHOOL BASED PESANTREN POLICY IN MADRASAH Mts, Tsanawiyah Furqon, A L Bantul, Sanden" 7 (2018): 226-40.

Yaqin, Muchammad Ainul. "PENDIDIKAN AGAMA ISLAM DAN PENANGGULANGAN KENAKALAN SISWA (Studi Kasus MTs Hasanah Surabaya)." Jurnal Pendidikan Agama Islam (Journal of Islamic Education Studies) 4, no. 2 (2016): 293. https:// doi.org/10.15642/ pai.2016.4.2.293-314.

Yusuf, Wiwin Fachrudin. "Hubungan Dukungan Sosial Dan Self Acceptance Dengan Motivasi Menghafal Al-Qur'an Di Pondok Pesantren Al-Qur'an Nurul Huda Singosari Malang." Jurnal Psikologi III, no. 1 (2015): 1-11. 